Volume 8. No. 9, September 2020

International Journal of Emerging Trends in Engineering Research

Available Online at http://www.warse.org/IJETER/static/pdf/file/ijeter96892020.pdf

https://doi.org/10.30534/ijeter/2020/96892020

\title{
Soil Synthesis and Identification of Nitrogen percentage in Soil using Machine learning algorithms and Augmented Reality - A Typical review
}

\author{
N Lakshmi Kalyani ${ }^{1}$, Kolla Bhanu Prakash ${ }^{2}$ \\ ${ }^{1}$ Research Scholar, Department of CSE, Koneru Lakshmaiah Education Foundation, Vaddeswaram, \\ Guntur(DST), Andhra Pradesh, India \\ ${ }^{2}$ Professor, Department of CSE, Koneru Lakshmaiah Education Foundation, Vaddeswaram, Guntur(DST), \\ Andhra Pradesh, India
}

\begin{abstract}
Soil nitrogen is the one of the primary nutrient plays a major role in achieving high crop yield. This paper mainly synthesizes importance of knowing percentage of nitrogen present in the soil, conventional laboratory testing methods, limitations of traditional techniques used and importance of nitrogen, rate of consumption during different stages of cultivation to achieve high yield, suitable soil for specific yield, potential. This paper also focused on the soil classification based on soil color approach, Machine learning algorithms, novel approaches used for nitrogen application to specific crop when consumption by the crop is more, the environmental effects due to excess use of nitrogen fertilizers and the research gaps., use of cutting edge technologies like augmented reality in future agriculture.
\end{abstract}

Key words : About four key words or phrases in alphabetical order, separated by commas.

\section{INTRODUCTION}

The word 'soil' comes from 'Solum' word, consists of mineral particles, organic matter, water, air \& living organisms called earth's crust hold the plant to grow [1]. Soil is crucial component in food production, quality of environment, sustainable soil management resources will generate large benefits like Biodiversity, food security and nutrition management, climate change adaption, water quality and quantity and Economic growth. Cultural system confirms adequate level of soil fertility and this practice was disturbed with excessive use of chemical fertilizers, pesticides and ample tillage to meet the world people hunger with limited land availability [18]. To ensure and improve agriculture productivity with desired nutrient supply, the nutrients present in the soil has to be monitored continuously. Soil fertility can be improved with conservation methods by retaining the residue on the surface of soil that decrease soil disturbance, and increase aggregation of soil, water infiltration and availability of nutrients [4].

Functionality of soil determined by soil quality and assessments depends on many aspects like process of static and chemical, physical changes and biological factors are need to be defined and these aspects are considered in determining soil management and environmental scenario [20]. It includes identification of land arable, diversification of crop, restoration of organic matter and rationalization soil input [5]. Soil classification is based on the soil fertility in olden day, but in modern days soil properties- color, texture and structure are also taken into consideration and in determining soil type [19].

According to "Indian Council of Agriculture Research (ICAR)" Indian soils are classified based on their character and nature as per USDA soil taxonomy Figure 1.
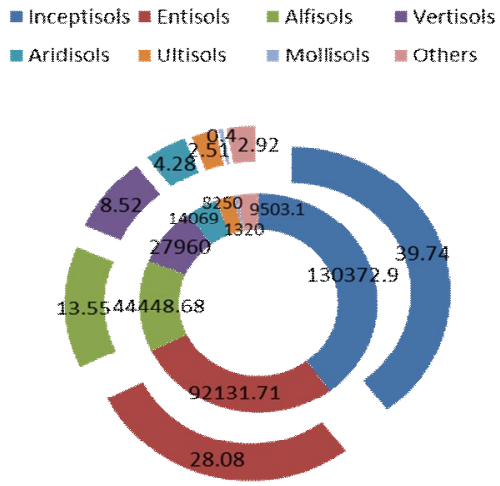

Figure 1: ICAR classification of Indian soils as per USDA Taxonomy

ICAR has Classified the soils based on their color, genesis, composition and location into: (1) Alluvial Soils, (2). Black Soils, (3). Red and Yellow Soils, (4). Laterite Soils. (5). Arid Soils, (6). Saline Soils, (7). Peaty Soils, (8). Forest Soils. 1.1 Alluvial Soils: These soils differ from sandy loam to clay in nature and light gray to ash gray in color.

1.2 Black Soil: these soils are clayey and water proof. Have different characters in different weather conditions like swell and sticky in wet conditions, shrikes in dried conditions and 
helps the crops to sustain in dried weather conditions due to slow absorption and loss moisture. These soils contain lime, iron magnesia and alumina and the color of this soil vary from deep black - grey [21].

1.3 Red and Yellow soils: Red and Yellow soils with fine texture are fertile and with rough texture are poor in fertile.[23] And the soils are in reddish color due to extensive diffusion of iron in crystalline and metamorphic rocks, become yellow when it happened in a hydrate form. [24] These soils contain less percentage of nitrogen, phosphorous and humus.[25]

1.4 Laterite Soils: these soils are result of intensive leaching due to high temperature and heavy rain fall. [26] These soils contain iron oxide and aluminium compounds, and with very less percentage of organic matter, nitrogen, phosphate and calcium. [27] Soils are looks in red colour [22].

1.5 Arid Soils: these soils are sandy in structure and contain high percentage of soil by evaporation of salt water due to low moisture, high temperature and humus. [28] These soils colour is varies from red to brown and contain low humus and organic matter. [29]

1.6 Salin/Usara Soils: These soils are vary from sandy to loamy, these soils are low in nitrogen and calcium and rich in proportion of sodium, potassium and magnesium. [30]

1.7 Peaty soils: These soils are rich in humus and organic content. These soils black in colour [17].

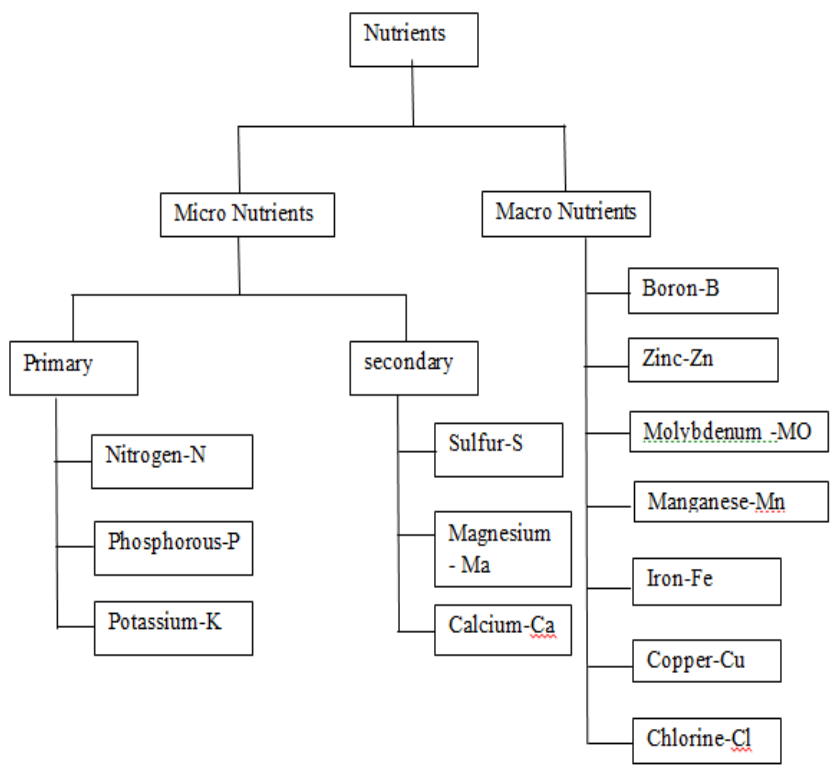

Figure 2: classification Soil nutrients

\subsection{Essential nutrients exist in the soil:}

Soil nutrients are classified as macro and micro nutrients [7]. Figure 2 details existing nutrients

The Government of india running many schemes to monitor soil health like Soil Health Card (SHE) started in 2015, under this scheme all the states follows distinctive principles for analyzing the soil to identify fertility related restrictions and also do the site specific fertilizer Suggestions[7]. This will process will done once in a three years after observing the soil regularity. Under this scheme nitrogen fertility status is shown in Figure 3

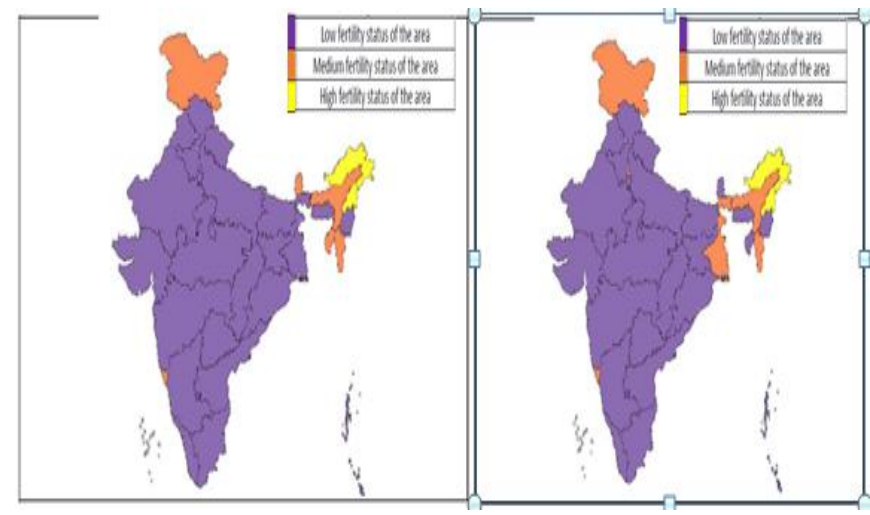

Figure 3: nitrogen fertility status under Soil Health Card (SHE)

Nitrogen is essential nutrient in rice yield [6]. Production of rice have increased the application of nitrogen fertilizer, and insufficient nutrient present in the soil be identified by leaf chlorophyll and decreased biomass and reduction in yield and quality [10]. Plants intake mineral form of nitrogen. Nitrogen available in form of Ammonium (NH+4) \& Nitrate (NO-3) [12].

Excessive application of nitrogen Usage of nitrogen will leave high level nitrogen this will contaminate water and effect the environmental pollution due to leaching. [31] Excessive usage of fertilizers may also affect the quality of crop. [32] Supply high level of nitrogen to the leafy vegetables may cause human diseases [16]. The main aim of introducing novel farming methods in adequate supply of nitrogen is for environment - friendly and cost effective [13]. Tissue analysis is used for determination of nitrogen but is time consuming[14]. Chlorophyll and polyphenols have been used in determining the Nitrogen level in plant. [33]

Determination of N Status in crop based on the transmittance properties of leaves and also canopy reflectance measurements [15]. Determination of $\mathrm{N}$ with chlorophyll fluorescence can come across restrictions with chlorophyll methods. Determination of $\mathrm{N}$ status estimated with the value of canopy reflectance $f$ a particular area. [34]

Table1: Anatomy of Plant N-Sensing techniques

\begin{tabular}{|c|l|l|l|}
\hline \multicolumn{2}{|l|}{ Methods } & $\begin{array}{l}\text { Advantag } \\
\text { es }\end{array}$ & $\begin{array}{l}\text { Disadvant } \\
\text { ages }\end{array}$ \\
\hline Tissue analysis & $\begin{array}{l}\text { Kjeldahl } \\
\text { digestion } \\
\text { digestion }\end{array}$ & $\begin{array}{l}\text { To estimate } \\
\text { total N } \\
\text { contents } \\
\text { (protein, } \\
\text { amino acids, } \\
\text { nucleic } \\
\text { acids, } \text { etc.). }\end{array}$ & $\begin{array}{l}\text { Invasive and } \\
\text { destructive. } \\
\text { Time-consum } \\
\text { ing. Toxic } \\
\text { reagents used. } \\
\text { Sample } \\
\text { preprocessing } \\
\text { requirements. }\end{array}$ \\
& & $\begin{array}{l}\text { No nitrate \& } \\
\text { nitrite } \\
\text { depletion. }\end{array}$ & $\begin{array}{l}\text { It may cause } \\
\text { damage. Loss } \\
\text { of nitrogen } \\
\text { because of } \\
\text { process } \\
\text { burning } \\
\text { Nitrogen }\end{array}$ \\
\cline { 2 - 4 } & Dumas \\
& combustion & & \\
& & &
\end{tabular}


N Lakshmi Kalyani et al., International Journal of Emerging Trends in Engineering Research, 8(9), September 2020, 5501 - 5505

\begin{tabular}{|c|c|c|c|c|c|}
\hline & & & & & $\begin{array}{l}\text { partially. } \\
\text { Preliminary } \\
\text { processing } \\
\text { needs. }\end{array}$ \\
\hline \multirow[t]{6}{*}{$\begin{array}{l}\text { Optica } \\
1 \\
\text { meters }\end{array}$} & \multirow[t]{3}{*}{$\begin{array}{l}\text { Leaf } \\
\text { level }\end{array}$} & $\begin{array}{l}\text { Tran } \\
\text { smitt } \\
\text { ance }\end{array}$ & SPAD & $\begin{array}{l}\text { Relation } \\
\text { between } \\
\text { Status of } \\
\text { Nitrogen \& } \\
\text { chlorophyll } \\
\text { presence in } \\
\text { the leaf. } \\
\text { Easily } \\
\text { movable. }\end{array}$ & $\begin{array}{l}\text { Excess } \\
\text { application of } \\
\text { fertilizer to } \\
\text { crops because } \\
\text { of saturation } \\
\text { point of leaf } \\
\text { chlorophyll. } \\
\text { And low } \\
\text { reactivity N } \\
\text { stress for } \\
\text { identification } \\
\text { at earliest } \\
\text { stages. }\end{array}$ \\
\hline & & \multirow[t]{2}{*}{$\begin{array}{l}\text { Fluo } \\
\text { resce } \\
\text { nce }\end{array}$} & Dualex & $\begin{array}{l}\text { Incorrect } \\
\text { signal from } \\
\text { uncovered } \\
\text { soil can be } \\
\text { get rid of. } \\
\text { Differentiat } \\
\text { e multiple N } \\
\text { treatments } \\
\text { under } \\
\text { sunlight } \\
\text { shadow. } \\
\text { Easily } \\
\text { movable. }\end{array}$ & \multirow[t]{2}{*}{$\begin{array}{l}\text { Still they are } \\
\text { unable to use } \\
\text { remote } \\
\text { sensors. } \\
\text { Instead, } \\
\text { fluorescence } \\
\text { sensors will } \\
\text { be used for } \\
\text { observing } \\
\text { sizable area } \\
\text { of crop in the } \\
\text { coming years. }\end{array}$} \\
\hline & & & Multiplex & $\begin{array}{l}\text { To identify } \\
\mathrm{N} \\
\text { deficiency. }\end{array}$ & \\
\hline & \multirow[t]{3}{*}{$\begin{array}{l}\text { Canop } \\
\text { y level }\end{array}$} & \multirow[t]{3}{*}{$\begin{array}{l}\text { Grou } \\
\text { nd-b } \\
\text { ased }\end{array}$} & $\begin{array}{l}\text { Passive } \\
\text { sensors: Field } \\
\text { Spec. } \\
\text { CropScan LI } \\
1800 .\end{array}$ & $\begin{array}{l}\text { Identify } \\
\text { sizable crop } \\
\text { field area } \\
\text { than leaf } \\
\text { level meters. }\end{array}$ & $\begin{array}{l}\text { It requires } \\
\text { calibration. } \\
\text { And } \\
\text { dependence } \\
\text { on sunlight. }\end{array}$ \\
\hline & & & $\begin{array}{l}\text { Digital } \\
\text { Cameras }\end{array}$ & $\begin{array}{l}\text { It Don't } \\
\text { require } \\
\text { sophisticate } \\
\text { d } \\
\text { instruments. }\end{array}$ & $\begin{array}{l}\text { It is sunlight } \\
\text { dependent. } \\
\text { Even though } \\
\text { recent } \\
\text { researchers } \\
\text { described the } \\
\text { use of fuzzy } \\
\text { logic } \\
\text { controllers } \\
\text { decreasing } \\
\text { the effects of } \\
\text { sunlight, and } \\
\text { most of } \\
\text { research } \\
\text { focused on } \\
\text { assessment of } \\
\text { crop N status } \\
\text { and more } \\
\text { analyses need } \\
\text { to be done }\end{array}$ \\
\hline & & & $\begin{array}{l}\text { Active } \\
\text { sensors: } \\
\text { GreenSeeker } \\
\text { Yara } \\
\text { N-Sensor } \\
\text { CropCircle }\end{array}$ & $\begin{array}{l}\text { There is no } \\
\text { sun-light } \\
\text { dependency. } \\
\text { Yara } \\
\text { records } \\
\text { more } \\
\text { biomass per } \\
\text { unit of } \\
\text { surface of } \\
\text { soil, } \\
\text { calculate \& } \\
\text { record wide } \\
\text { waveband. } \\
\text { GreenSeeke } \\
\mathrm{r} \text { reports } \\
\text { variation in } \\
\text { crop canopy }\end{array}$ & $\begin{array}{l}\text { Equipment } \\
\text { cost. } \\
\text { Saturation } \\
\text { due to the } \\
\text { biomass } \\
\text { increasing. } \\
\text { GreenSeeker } \\
\text { measures } \\
\text { only two } \\
\text { wavelengths. } \\
\text { Yara did not } \\
\text { detect plant } \mathrm{N} \\
\text { status. } \\
\text { GreenSeeker } \\
\text { reaches } \\
\text { saturation } \\
\text { earlier than }\end{array}$ \\
\hline
\end{tabular}

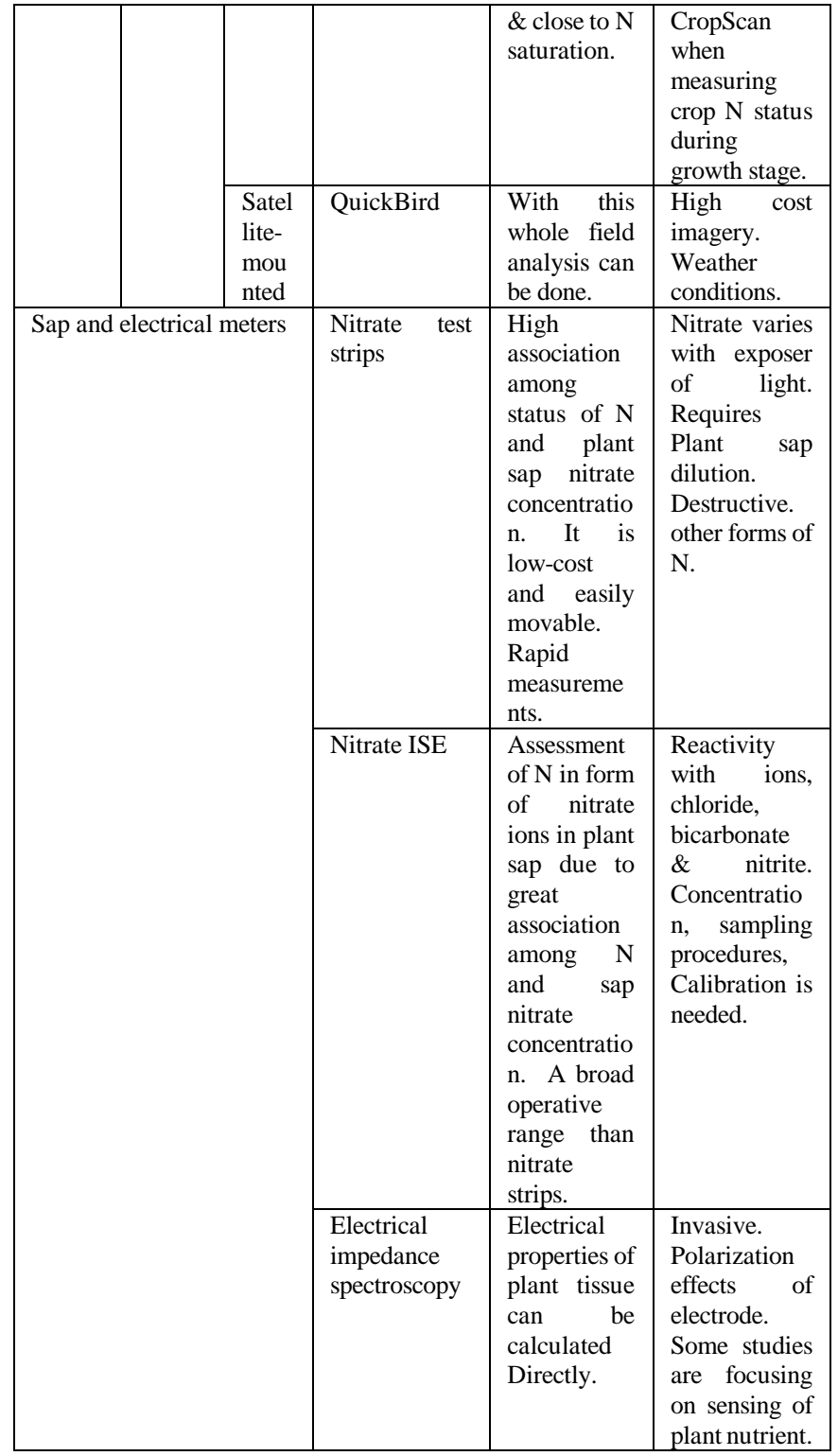

\section{CONCLUSION}

To reduce the environmental and economic effect, balancing $\mathrm{N}$ - fertilizer is major concern. Tissue analysis methods used to determine plant $n$ Status. And plant optical properties need to be used in addition to determining $\mathrm{N}$ Status to identify excessive usage of Nitrogen, overall optical analysis for $\mathrm{N}$-status estimation need to be improved.

\section{REFERENCES}

1. EnviStats. Soil nutrients indices. Environment Accounts, India, Vol. II, 201 .

2. H PATHAK Trend of fertility status of Indian soils. Current Advances in Agricultural Sciences 2(1): 10-12 (June 2010) Division of Environmental Sciences, Indian Agricultural Research Institute, New Delhi 110012.

3. Warkentin, B.P. The changing concept of soil quality. Soil Water Conserv. 50:226-228. 1995. 
N Lakshmi Kalyani et al., International Journal of Emerging Trends in Engineering Research, 8(9), September 2020, 5501 - 5505

4. Lal R. The potential of carbon sequestration in soils of south Asia. In: Conserving Soil and ater for Society: Sharing Solutions. 13th International Soil Conservation Organisation Conference. Brisbane. pp. 1-6. 2004.

5. Martin R. Carter*. Soil Quality for Sustainable Land Management: Organic Matter and Aggregation Interactions that Maintain Soil Functions. AGRONOMY JOURNAL, VOL. 94, JANUARY-FEBRUARY 2002.

6. Yoshida S. Physiological analysis of rice yield. Yoshida $S$, editor. International rice research institute. Los Banos, Philippines: Fundamentals of Rice Crop Science; 1981. p. 231-47.

7. J.W.Doran, A thin layer of soil covering the surface of the earth is the major interface between agriculture and the environment, and represents the difference between survival and extinction for most land based life. EnviStats. Environment Accounts Vol. II India, 2019.

8. Ponnamperuma FN, Deturck PA. Review of fertilization in rice production. Intl Rice Comm Newsl 1993;42:1-12.

9. Prasertsak A, Fukai S. Nitrogen availability and water stress interaction on rice growth and yield. Field Crop Res. 1997. 52: 249-60.

10. Rambo L, Ma B, Xiong Y, Ferreira da Silvia P. Leaf and canopy optical characteristics as crop- $\mathrm{N}$-status indicators for field nitrogen management in corn. $J$ Plant Nutr Soil Sci 2010;173:434-43.

11. Taiz, L.; Zeiger, E. Plant Physiology, 5th ed.; Sinauer Associates Inc.: Sunderland, MA, USA, 2010; pp. 67-86.

12. Demotes-Mainard, S., Boumaza, R., Meyer, S., Cerovic, Z.G. Indicators of nitrogen status for ornamental woody plants based on optical measurements of leaf epidermal polyphenol and chlorophyll contents. Sci. Hort. 2008, 115, 377-385.

13. Li, Y.; Chen, D.; Walker, C.N.; Angus, J.F. Estimating the nitrogen status of crops using a digital camera. Field Crop. Res. 2010, 118, 221-227.

14. Rafael F. Muñoz-Huerta. A Review of Methods for Sensing the Nitrogen Status in Plants: Advantages, Disadvantages and Recent Advances. Sensors 2013, 10823-10843; doi:10.3390/s130810823

15. K. M. Atikur Rahman and Dunfu Zhang. Effects of Fertilizer Broadcasting on the Excessive Use of Inorganic Fertilizers and Environmental Sustainability . Sustainability 2018, 10, 759;

16. Dharmapuri, S. L., Dandamudi, P. K., Botcha, V. M., Kolla, B. P. Detecting central nervous system disorder using machine learning technique (XGB classifier). International Journal of Emerging Trends in Engineering Research, 8(4), 1142-1147. doi:10.30534/ijeter/2020/31842020

17. Enireddy, V., Gunda, K., Kalyani, N. L., \& Prakash, K. B. Nature inspired binary grey wolf optimizer for feature selection in the detection of neurodegenerative (parkinson) disease. International
Journal of Advanced Trends in Computer Science and Engineering, $\quad$ 9(3), 3977-3987. doi:10.30534/ijatcse/2020/222932020.

18. Babitha, D., Ismail, M., Chowdhury, S., Govindaraj, R., \& Prakash, K. B. Automated road safety surveillance system using hybrid cnn-Istm approach. International Journal of Advanced Trends in Computer Science and Engineering. $9(2), \quad 1767-1773$. doi:10.30534/ijatcse/2020/132922020

19. Babitha, D., Jayasankar, T., Sriram, V. P., Sudhakar, S., \& Prakash, K. B. Speech emotion recognition using state-of-art learning algorithms. International Journal of Advanced Trends in Computer Science and Engineering, $\quad$ 9(2), 1340-1345. doi:10.30534/ijatcse/2020/67922020.

20. Bharadwaj, Y. S. S., Rajaram, P., Sriram, V. P., Sudhakar, S., \& Prakash, K. B. Effective handwritten digit recognition using deep convolution neural network. International Journal of Advanced Trends in Computer Science and Engineering, 9(2), 1335-1339. doi:10.30534/ijatcse/2020/66922020

21. Prakash, K., Lakshmi Kalyani, N., Vadla, P. K., \& Naga Pawan, Y. V. R. Analysis of mammography for identifying cancer cells using convolution neural networks. International Journal of Advanced Trends in Computer Science and Engineering, 9(2), 1184-1188. doi:10.30534/ijatcse/2020/44922020

22. Prakash, K. B., Nagapawan, Y. V. R., Kalyani, N. L., Kumar, V. P. Chatterbot implementation using transfer learning and LSTM encoder-decoder architecture. International Journal of Emerging Trends in Engineering Research, 8(5), 1709-1715. doi:10.30534/ijeter/2020/35852020.

23. Ismail, M., Prakash, K.B. and Rao, M.N., 2018. Collaborative filtering-based recommendation of online social voting. International Journal of Engineering and Technology (UAE), 7(3), pp.1504-1507.

24. Prakash, K.B. and Rajaraman, A., 2016. Mining of bilingual Indian Web documents. Procedia Computer Science, 89, pp.514-520.

25. Prakash, K.B., Rangaswamy, M.D., Ananthan, T.V. and Rajavarman, V.N., 2015. Information extraction in unstructured multilingual web documents. Indian Journal of Science and Technology, 8(16), pp.1-8.

26. Prakash, K.B., Rangaswamy, M.D. and Raman, A.R., 2012, November. ANN for multi-lingual regional web communication. In International Conference on Neural Information Processing, Springer, Berlin, Heidelberg, pp. 473-478.

27. Prakash, K.B., Rangaswamy, M.D. and Raman, A.R., 2012, August. Statistical interpretation for mining hybrid regional web documents. In International Conference on Information Processing Springer, Berlin, Heidelberg, pp. 503-512.

28. Prakash, K.B., 2016, July. Content extraction studies using total distance algorithm. In 2016 2nd International Conference on Applied and Theoretical 
N Lakshmi Kalyani et al., International Journal of Emerging Trends in Engineering Research, 8(9), September 2020, 5501 - 5505

Computing and Communication Technology (iCATccT) IEEE, pp. 673-679.

29. Prakash, K.B., 2015. Mining issues in traditional Indian web documents. Indian Journal of Science and Technology, 8(32), pp.1-11.

30. Prakash, K.B., RajaRaman, A. and Lakshmi, M., 2017, March. Complexities in developing multilingual on-line courses in the Indian context. In 2017 International Conference on Big Data Analytics and Computational Intelligence (ICBDAC) IEEE, pp. 339-342.

31. Prakash, K.B., Kumar, K.S. and Rao, S.U.M., 2016, July. Content extraction issues in online web education. In 2016 2nd International Conference on Applied and Theoretical Computing and Communication Technology (iCATccT) IEEE, pp. 680-685.

32. Prakash, K.B., RajaRaman, A., Perumal, T. and Kolla, P.,Foundations to frontiers of big data analytics. In 2016 2nd International Conference on Contemporary Computing and Informatics (IC3I), IEEE, pp. 242-247.

33. Vadla, P.K. and Prakash, K.B., 2020. Residue based adaptive resource provisioning through multi-criteria decision and horizontal scaling of vm's in agent-based model for federated cloud. International Journal of Advanced Trends in Computer Science and Engineering, 9(2), pp.1610-1622.

34. Kavuri, M., \& Prakash, K. B. (2019). Performance comparison of detection, recognition and tracking rates of the different algorithms. International Journal of Advanced Computer Science and Applications, 10(6), pp.153-158 